\title{
Interannual variation of strobilation by the scyphozoan Aurelia labiata in relation to polyp density, temperature, salinity, and light conditions in situ
}

\author{
Jennifer E. Purcell ${ }^{*}$, Richard A. Hoover, Nathan T. Schwarck \\ Western Washington University, Shannon Point Marine Center,1900 Shannon Point Rd. Anacortes, Washington 98221, USA
}

\begin{abstract}
Jellyfish are important components of aquatic ecosystems and may interfere with human priorities through damage to fisheries, tourism, and power production. Jellyfish populations are renowned for large, unexplained outbreaks (blooms) that may be affected by polyp density and environmental factors, including temperature, salinity, light, and food. In this study, 14 to 15 sites underneath marina floats were monitored by monthly photographs; temperature, salinity, and light intensities were recorded beneath the floats from December through March in $3 \mathrm{yr}$ in order to quantify the amounts and times of strobilation of the moon jellyfish Aurelia labiata in relation to polyp density and environmental factors in Cornet Bay, Washington, USA. Strobilation occurred during February 2004 (Year 1), January and February 2005 (Year 2), and February to April 2006 (Year 3), when temperature, salinity, and light were increasing after the annual minima. Polyps averaged $58 \%$ cover and densities of $9.3 \mathrm{~cm}^{-2}$ with little variation among years. Polyp densities were not correlated with the amounts or start times of strobilation. By contrast, the amounts and times of strobilation and all physical factors tested (temperature, salinity/precipitation, light) differed significantly among years. Strobilation was greatest ( $63 \%$ of polyps) and earliest in Year 2, when pre-strobilation temperature and daily light exposure were high and precipitation was low. The differences in amounts and times of strobilation were greater than predicted from previous laboratory experiments, thus suggesting additive effects of environmental factors. Warm temperatures, nutrient delivery from run-off, and high sunlight enhance plankton production, providing abundant food for the polyps and new jellyfish, and those environmental cues synchronize jellyfish and plankton production.
\end{abstract}

KEY WORDS: Warming $\cdot$ Photoperiod $\cdot$ Jellyfish $\cdot$ Bloom $\cdot$ Climate $\cdot$ Reproduction $\cdot$ Density-dependent Puget Sound

Resale or republication not permitted without written consent of the publisher

\section{INTRODUCTION}

Outbreaks of gelatinous zooplankton species are generally considered detrimental to human interests (reviewed by Purcell et al. 2007). For example, jellyfish affect human health and recreation, are both predators and competitors of fish, clog fishing nets, cause mass mortalities of fish in aquaculture pens, and interrupt power plant operations. An unprecedented number of jellyfish outbreaks have been reported in the 1990s and 2000s, which may be due to a combination of climate effects and anthropogenic modification of the environment (reviewed by Purcell et al. 2007).

Recent correlations of gelatinous predator populations with climate variables show the importance of climate in determining their population sizes (reviewed by Purcell 2005, Purcell et al. 2007). Temperature has important effects. Most species (13 of 16 species examined) have large populations in warm conditions. Experiments show accelerated and increased production of jellyfish in response to warm temperatures (reviewed by Purcell 2007, see also Liu et al. 2009). Salinity is also an important factor. Abundances of 
some species have been correlated with high salinities (Goy et al. 1989, Purcell et al. 1999, Molinero et al. 2005). Laboratory experiments show significant effects of salinity on asexual reproduction (reviewed by Purcell 2007). High sunlight (insolation) is also related to abundant jellyfish in situ (Hernroth \& Gröndahl 1985, Molinero et al. 2005, Purcell \& Decker 2005), and greater light exposure accelerates jellyfish production in the laboratory (Loeb 1973, Purcell 2007, Liu et al. 2009). Given that climate models project global ocean warming and changes in precipitation and cloud cover for the foreseeable future (e.g. IPCC 2007), jellyfish populations would be expected to be affected.

The life cycle of most scyphomedusae and many hydromedusae includes a perennial clonal polyp stage that asexually buds more polyps and new jellyfish. For scyphozoans, the production of new jellyfish (ephyrae) is called strobilation. Population sizes of many jellyfish reflect the success of this benthic polyp stage in producing jellyfish. In comparison with the swimming medusa stage, little is known about the polyps. Very few ecological studies exist for polyps in situ, and most of those used settling plates, which present artificial substrates (e.g. Hernroth \& Gröndahl 1985, Watanabe \& Ishii 2001). Our goal was to examine environmental factors that may cause interannual differences in strobilation in situ.

Several conditions have been associated with strobilation including (1) an inverse correlation between polyp density and the onset of strobilation (Silverstone et al. 1977, Keen 1991, Willcox et al. 2008), (2) warm temperatures in laboratory experiments increasing ephyra production and accelerating strobilation (Purcell et al. 1999, Purcell 2007), (3) cooling preceding and during strobilation (e.g. Lucas 2001, Liu et al. 2009), (4) decreased salinity or rainstorms preceding jellyfish appearance (Lu et al. 1989, Rippingale \& Kelly 1995, Pitt \& Kingsford 2003, Gordon et al. 2004), (5) increased light accelerating strobilation (Loeb 1973, Purcell 2007), and (6) changed food availability affecting strobilation (e.g. Spangenberg 1968, Purcell et al. 1999, Purcell 2007). The present study was designed to examine these potential connections to strobilation.

Moon jellyfish in the genus Aurelia have a global distribution and are responsible for problem blooms in many areas (reviewed by Purcell et al. 2007). A. labiata is the native species in northeast Pacific from central California to the Gulf of Alaska. In the present study, we quantify polyp densities and the numbers of strobilating polyps for A. labiata concurrently with in situ temperature, salinity, and light intensities in waters of the Puget Sound, Washington, USA. We tested several null hypotheses $\left(H_{0}\right)$ to explain interannual variation in the numbers of strobilating polyps and the time of strobilation.

\section{MATERIALS AND METHODS}

The Cornet Bay Marina is a small, private marina with 60 slips for recreational vessels on the north shore of Whidbey Island, WA $\left(48^{\circ} 24^{\prime} \mathrm{N}, 122^{\circ} 38^{\prime} \mathrm{W}\right)$. Little boating activity occurs during winter months, and no repairs, construction, or dredging occurred during the period of our study (M. Woods pers. comm.). The polyps of Aurelia labiata cover the underside of the marina's covered floating docks. There appear to be dozens of individual clones that vary in area from a few square centimeters to several square meters. The population is estimated to cover a total area of approximately $685 \mathrm{~m}^{2}$ with over 100 million individuals.

Monthly photographs were taken between December 2003 and April 2005 at 15 sites and December 2005 and April 2006 at 14 sites distributed underneath two $2.5 \times 15$ m marina floats in Cornet Bay. A Nikonos 5 underwater SLR camera with a $35 \mathrm{~mm}$ lens, a 1:2 extension tube, and a Nikonos SB-105 strobe were used by a diver for all photographs. In order to photograph exactly the same areas, the lower left hand corner of a $5 \times 7 \mathrm{~cm}$ metal framer was placed around each sitemarking screw when the photographs were taken. All photographs were taken with an aperture of F22 and minimum focal distance on Kodak EliteChrome 36 exposure slide film, ISO 200.

The photographs were analyzed to determine percentage cover of Aurelia labiata polyps and whether the polyps were strobilating. Non-strobilating polyps were white but became orange during strobilation. The photographic slides were first converted to a Bitmap digital format using an EPSON Perfection 2450 Photo scanner and processed using the OPTIMUS 6.0 image analysis software package. Due to low variance in color thresholds between polyps and substrates, a Wallis filter with a desired average of 100, a standard deviation of 75, and a variance threshold of 16 was applied to the images in order to better define edges and increase contrast between the polyps and the background. To further ensure reproducible measurement, color thresholds were standardized for each survey location, and each slide was separately scanned for the presence of other fouling organisms. The percentage cover of polyps was determined by measuring the covered area falling within the range of the color thresholds.

When strobilation was seen, the numbers of strobilating and non-strobilating polyps were counted by eye from the enlarged images. Polyp density at each site was calculated from the number of polyps divided by site area $\left(35 \mathrm{~cm}^{2}\right)$. The stages of strobilation were distinguished as follows: (1) early strobila (segmented), (2) mid strobila (pale orange in color with ephyrae partly formed), and (3) advanced strobila (dark orange 
with ephyrae well-developed). These stages were assigned values of 1 to 3 , and the numbers of strobilae in each stage were multiplied by the corresponding value in order to calculate the strobilation stage index (SSI) at each site (Table 1).

Physical conditions under the marina floats were monitored from December 2003 to April 2005, and from December 2005 to April 2006. Temperature and salinity were recorded at polyp depth of $\sim 0.5 \mathrm{~m}$ at hourly intervals with a Hydrolab MiniSonde 4a from December 2003 to April 2005. Temperature and light were recorded at $5 \mathrm{~min}$ intervals with a HOBO U12-012 Onset data logger in a custom acrylic housing mounted underneath a float among polyps at about $0.5 \mathrm{~m}$ depth from December 2004 to April 2005 and from December 2005 to April 2006. Onset light data were recorded in lumens $\mathrm{m}^{-2}$ (lux) and measured light conditions experienced by the polyps. The accuracy of the HOBO logger is given as $\pm 2.5 \%$ temperature and $\pm 20 \%$ for light. Discontinuities in the data resulted from occasional use of the Hydrolab by other investigators, for calibration, and from equipment repair.

Table 1. Aurelia labiata. Numbers of strobilating polyps at 14 to 15 sites $(2003-4=$ Year 1, 2004-5 = Year 2) and 14 sites (2005-6 = Year 3$)$ photographed monthly underneath floats at the Cornet Bay marina, Washington, USA. All polyps were counted only when strobilation occurred at a site; therefore, total polyps in other months were estimated. Percentages of polyps strobilating are means \pm SE and ranges. The strobilation stage index was calculated from the numbers of polyps in early (1), mid (2), or advanced (3) strobilation. NA: not applicable

\begin{tabular}{|c|c|c|c|c|c|}
\hline \multirow[t]{2}{*}{ Date } & \multirow{2}{*}{$\begin{array}{c}\text { Total } \\
\text { polyps } \\
\text { (no.) }\end{array}$} & \multirow{2}{*}{$\begin{array}{l}\text { Sites with } \\
\text { strobi- } \\
\text { lation (no.) }\end{array}$} & \multicolumn{2}{|c|}{$\begin{array}{c}\text { Polyps } \\
\text { strobilating }\end{array}$} & \multirow{2}{*}{$\begin{array}{l}\text { Strobila- } \\
\text { tion stage } \\
\text { index }\end{array}$} \\
\hline & & & (no.) & $(\%)$ & \\
\hline \multicolumn{6}{|l|}{ Year 1} \\
\hline 17 Jan 04 & $\sim 5000$ & 0 & 0 & 0 & NA \\
\hline 17 Feb 04 & $\sim 5000$ & 8 & 1327 & $\begin{array}{c}22.6 \pm 9.7 \\
0-96.2\end{array}$ & 1.31 \\
\hline 25 Mar 04 & $\sim 5000$ & 1 & 10 & $0-3.5$ & 1.90 \\
\hline 20 Apr 04 & $\sim 5000$ & 0 & 0 & 0 & NA \\
\hline \multicolumn{6}{|l|}{ Year 2} \\
\hline 18 Jan 05 & $\sim 5000$ & 5 & 1689 & $\begin{array}{c}22.8 \pm 1.1 \\
0-96.8\end{array}$ & 1.56 \\
\hline 22 Feb 05 & 5222 & 15 & 2170 & $\begin{array}{l}41.2 \pm 7.6 \\
1.5-90.7\end{array}$ & 1.99 \\
\hline 18 Mar 05 & $\sim 5000$ & 2 & 40 & $\begin{array}{c}0.8 \pm 0.6 \\
0-7.9\end{array}$ & 2.97 \\
\hline 26 Apr 05 & $\sim 5000$ & 0 & 0 & 0 & NA \\
\hline \multicolumn{6}{|l|}{ Year 3} \\
\hline 10 Jan 06 & $\sim 4400$ & 0 & 0 & 0 & NA \\
\hline 8 Feb 06 & 4377 & 13 & 585 & $\begin{array}{c}13.1 \pm 3.2 \\
0-33.9\end{array}$ & 1.15 \\
\hline 8 Mar 06 & 4463 & 13 & 1867 & $\begin{array}{c}42.0 \pm 10.3 \\
0-95.8\end{array}$ & $3 \quad 2.34$ \\
\hline 4 Apr 06 & 4165 & 2 & 7 & $0-1.3$ & 0 \\
\hline
\end{tabular}

Because in situ salinity data were unavailable after 18 January 2005, we used daily precipitation statistics from the Seattle-Tacoma International Airport Station of the National Weather Service $90 \mathrm{~km}$ distant from Cornet Bay. Data given in inches were converted to millimeters. Daily totals of precipitation were used to compare the 3 pre-strobilation periods $(2003-4=$ Year 1, 2004-5 = Year 2, 2005-6 = Year 3).

Additional irradiance data were collected near the Shannon Point Marine Center (SPMC) $9 \mathrm{~km}$ distant from Cornet Bay. A Licor LI-190SA quantum sensor was positioned on top of the mast ( 8 $\mathrm{m}$ high) of the SPMC RV 'Anova'; a LI-1400 data-logger recorded for 5 s every 5 min and calculated daily totals of photosynthetically active radiation (PAR). Daily pre-strobilation above-water totals correlated poorly with in situ totals $\left(R^{2}=0.0155\right)$ because of shading by the floats, and so above-water data were used only to illustrate the annual insolation pattern (Fig. 1).

Data are presented as means \pm standard error (SE). Transformations and tests are given with each result.

\section{RESULTS}

\section{Annual patterns of Aurelia labiata polyps and environmental factors}

Fifteen sites underneath the Cornet Bay marina were monitored between December 2003 and March 2005 in order to assess annual patterns in polyp colony size and the time of strobilation relative to environmental factors (Fig. 1). Polyps covered $58.3 \pm 0.6 \%$ of the available surface area beneath the marina floats averaged over all dates and sites. Densities of polyps ranged from 6 to 13 polyps $\mathrm{cm}^{-2}$ and averaged $9.3 \pm$ $0.2 \mathrm{~cm}^{-2}$. Strobilation was observed during February 2004 and January and February 2005, when light, temperature, and salinity were near the lowest levels of the year (Fig. 1A,B). The number of disks polyp ${ }^{-1}$, which indicates how many jellyfish will be produced per polyp, ranged from 3 to 19 and averaged $10.1 \pm 3.4$ in February 2004. Immediately following strobilation in 2004 and 2005, the mean percentage cover of polyps decreased abruptly from over 60 to $45-50 \%$. This change was probably due to biomass loss from strobilation (Fig. 2C). During the summer, polyps increased the areas covered, presumably by budding and growth, and possibly by recruitment of planulae. Data on the percentage cover of polyps were arcsine square root transformed to achieve normal distributions. The percentage cover of polyps differed significantly among months (Friedman repeated measures analysis of variance [RM ANOVA] on ranks, $\chi^{2}{ }_{15}=119.073$, $\mathrm{p}<0.001$ ). Two groups were distinct (Tukey test), 

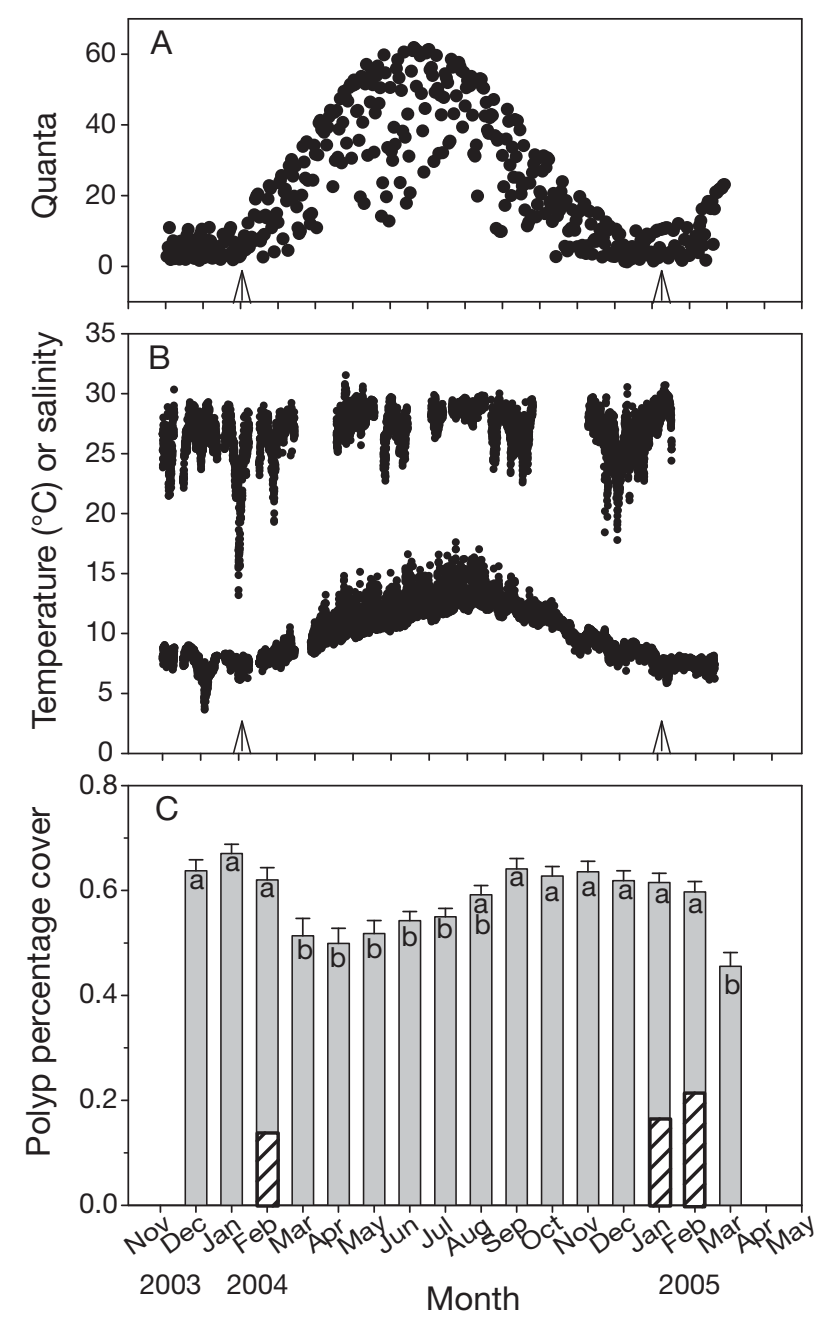

Fig. 1. Annual patterns of (A) sunlight (quanta $=1.9865 \mathrm{e}^{-25} \times$ $\mu \mathrm{mol}$ photons $\left.\mathrm{m}^{-2} \mathrm{~s}^{-1}\right)$, (B) water temperature $\left(5\right.$ to $15^{\circ} \mathrm{C}$ ) and salinity, and (C) percentage cover (mean $\pm \mathrm{SE}$ ) of Aurelia labiata polyps under marina floats in Cornet Bay, Washington, USA, from 1 December 2003 to 31 March 2005 (Year 1 and Year 2). Data in (A) are daily means above water; data in (B) are hourly measurements in the marina. Approximate dates when strobilation began are marked by arrows in A and B. Data in (C) are from monthly samples, and strobilation is indicated by hatched bars. Different letters $(\mathrm{a}, \mathrm{b})$ indicate significantly different multiple comparison groups

specifically before strobilation (Group A) and after strobilation (Group B), which covered less surface area than Group A sites.

\section{Interannual variation in strobilation}

The same sites were monitored, beginning in December and continuing through strobilation, during 3 periods (2003-4, 2004-5, and 2005-6, i.e. Year 1, Year 2, and Year 3, respectively). All sites had strobilating
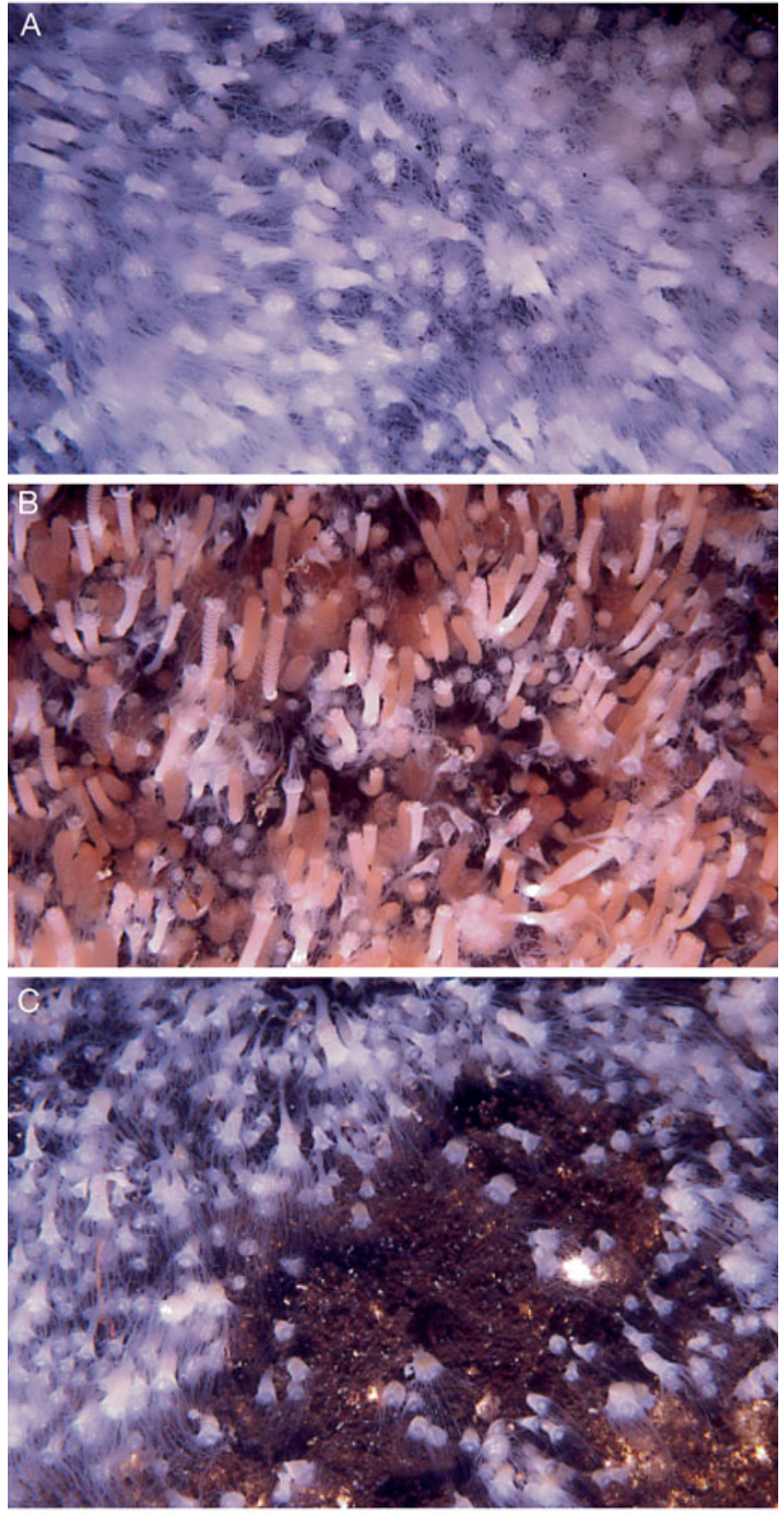

Fig. 2. Aurelia labiata. Polyps photographed from 1 site underneath marina floats in Cornet Bay, Washington, USA. (A) Pre-strobilation on 17 January 2004; (B) during strobilation on 17 February 2004; and (C) post-strobilation on 25 March 2004. Dimensions of site $=5 \times 7 \mathrm{~cm}$

polyps in Year 2 and all but 1 did in Year 3; by contrast, polyps in only $53 \%$ of the sites strobilated in Year 1 (Table 1). The maximum percentage of polyps that strobilated at any site was about $96 \%$ every year (Table 1). The total numbers of strobilating polyps differed greatly among years: 1337 in Year 1, 3281 in Year 2, and 2349 in Year 3 (Fig. 3). Thus, the greatest strobilation occurred in Year 2. Data representing the number of polyps strobilating at each site were then 


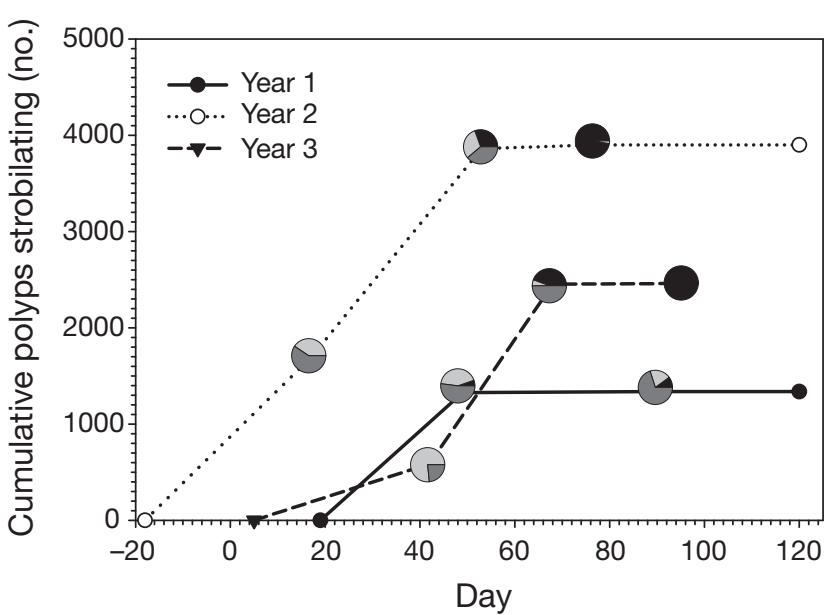

Fig. 3. Aurelia labiata. Cumulative numbers of polyps strobilating during 3 periods in Cornet Bay, Washington, USA. Points plotted are the totals of 15 sites in 2003-4 (Year 1) and 2004-5 (Year 2), and 14 sites in 2005-6 (Year 3). When strobilation was observed, the data points show the proportions of polyps in early (light gray), mid (medium gray), and late (black) strobilation. Days are numbered with 1 January as Day 1

$(x+1) \log _{10}$ transformed to achieve normal distributions. The numbers of strobilating polyps differed significantly among years (1-way RM ANOVA, $F_{2,43}=$ 13.595, p < 0.001; Table 2), with Year 1 differing significantly from both Year 2 (Holm-Sidak multiple comparisons, $t=4.936, \mathrm{p}<0.001)$ and Year $3(t=3.855, \mathrm{p}<$ 0.001).

The degree of strobila development enabled us to approximate the dates that strobilation began each year. Polyps were in early to mid-strobilation by midJanuary in Year 2 and in mid-February in Year 1 and Year 3 (Fig. 3). Because complete strobilation of Aurelia labiata in the laboratory at $7^{\circ} \mathrm{C}$ required about 1 mo (Purcell 2007), we used one-half of the number of days (15 to $19 \mathrm{~d}$ ) between no- and first-observedstrobilation divided by the SSI for each site. Thus, the estimated start days of strobilation were Day $30 \pm 1$ in Year 1, Day $-6 \pm 1$ in Year 2, and Day $32 \pm 0.5$ in Year 3. Days are numbered with 1 January as Day 1, thus 30 December is Day -1 . The start days of strobilation

Table 2. Aurelia labiata. Numbers of polyps strobilating (means $\pm \mathrm{SE}$ ) by month in each year $(2003-4=$ Year $1,2004-5=$ Year 2, 2005-6 = Year 3) at sites underneath marina floats in Cornet Bay, Washington, USA. The numbers of sites monitored are in parentheses after each year

\begin{tabular}{|lrrrrr|}
\hline \multirow{2}{*}{ Year } & \multicolumn{4}{c}{ Month } & \multirow{2}{*}{ Total } \\
\cline { 3 - 5 } & January & February & March & April & \\
\hline Year 1 (15) & 0 & $88.5 \pm 39.4$ & $0.7 \pm 0.7$ & 0 & $89.1 \pm 39.3$ \\
Year 2 (15) & $112.6 \pm 43.0$ & $144.7 \pm 28.6$ & $2.7 \pm 2.0$ & 0 & $259.9 \pm 44.3$ \\
Year 3 (14) & 0 & $41.8 \pm 10.6$ & $133.4 \pm 32.5$ & $0.5 \pm 0.3$ & $175.6 \pm 37.4$ \\
\hline
\end{tabular}

differed significantly among years (RM 1-way ANOVA, $F_{2,35}=840.466, \mathrm{p}<0.001$ ), with Year 2 differing significantly from both Year 1 (Holm-Sidak multiple comparisons, $t=29.422, \mathrm{p}<0.001)$ and Year $3(t=$ 38.148, p < 0.001). Strobilation began 1 mo earlier in Year 2 than in the other years (Fig. 3). As the season progressed in Year 2, polyps were in advanced strobilation by February, and $<1 \%$ were still strobilating in mid-March. In Year 1, almost all strobilation (95\%) occurred in February with a few strobilae in March. In Year 3, strobilation began in February and continued through March and into April, when $1.7 \%$ of the polyps were strobilating (advanced).

Because more polyps strobilated and strobilation occurred earlier in Year 2 than in Year 1 or Year 3, we tested factors that may have contributed to the observed differences. Temperature, salinity, and light were monitored nearly continuously underneath the marina floats before and throughout strobilation. The duration between initiating experimental conditions and strobilation averaged $44 \mathrm{~d}$ in the laboratory under ambient conditions $\left(7^{\circ} \mathrm{C}, 27\right.$ salinity; Purcell 2007); therefore, December to early January was probably when strobilation was triggered for polyps in Year 2. We compared pre-strobilation (1 December to 6 January) conditions among years that could indicate which factors favored strobilation in Year 2. We tested several null hypotheses as follows

- $H_{01}$ : the densities of polyps did not differ among years. Polyp densities in February for all sites in were similar in all years, averaging 8 to 10 polyps $\mathrm{cm}^{-2}$ (Fig. 4); however, the slightly decreased density in Year 3 led to a difference among years (1-way RM ANOVA), with no significant Holm-Sidak pair-wise comparisons (Table 3 ). $H_{01}$ was rejected. Nevertheless, differences in polyp density could not explain the marked differences in amount and time of strobilation between Year 1 and Year 2.

- $H_{02}$ : the percentages of polyps strobilating were independent of the polyp densities. The total percentages of polyps strobilating were plotted against polyp densities in February for all sites in Year 1, Year 2, and Year 3 (Fig. 4B). The percentages of polyps strobilating were poorly correlated with polyp densities in all years (Pearson product moment correlation, $R=0.201, \mathrm{p}=0.190) . H_{02}$ could not be rejected.

- $H_{03}$ : the start of strobilation was independent of the polyp densities. The estimated dates that polyps began strobilating were plotted against polyp densities in February for all sites in Year 1, Year 2, and Year 3 (Fig. 4C). Start days were not significantly correlated with polyp densities in all years 

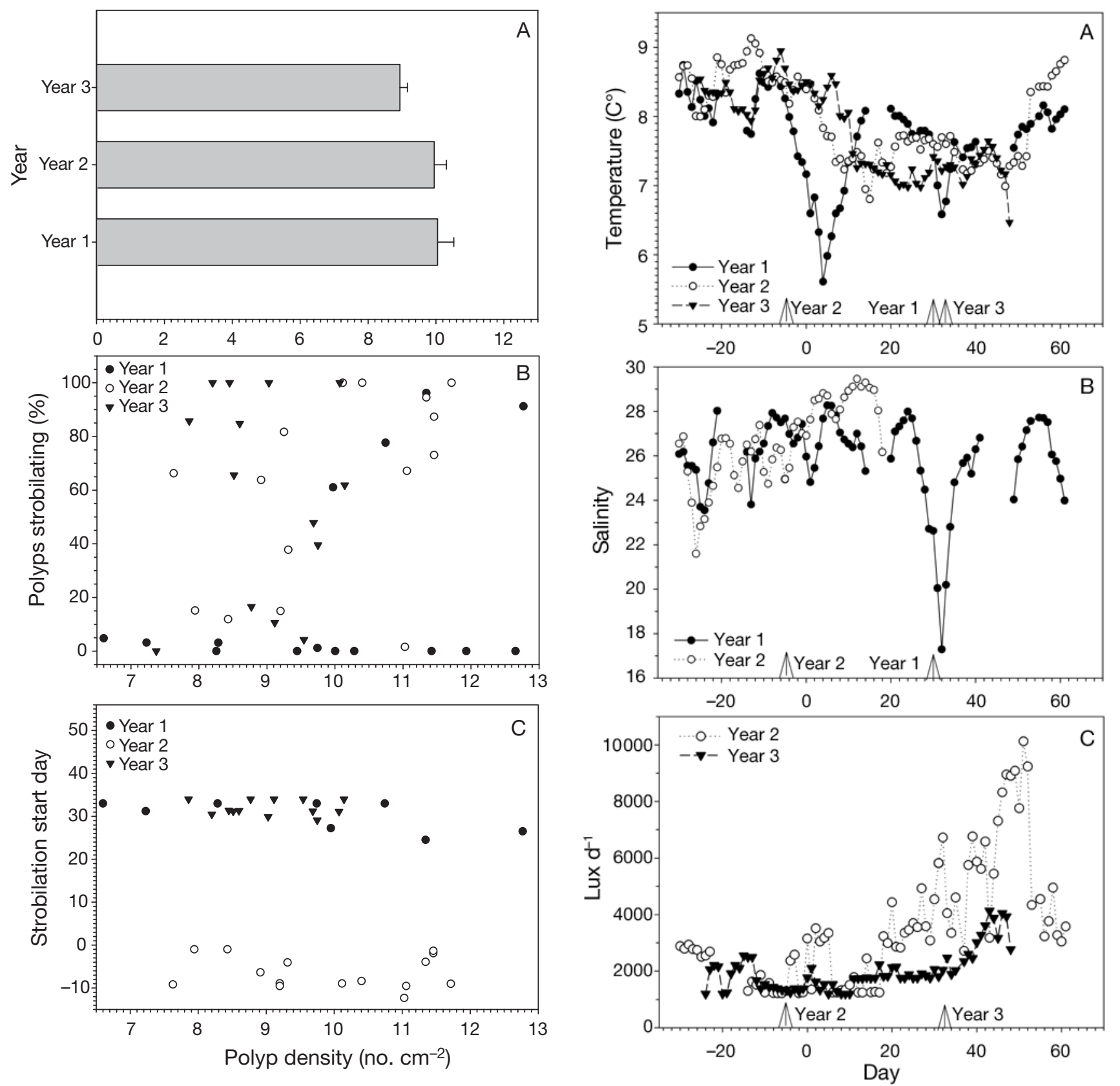

Fig. 4. Aurelia labiata. (A) Polyp densities in Cornet Bay, Washington, USA, (B) the percentages of polyps strobilating in relation to polyp densities, and (C) the estimated day on which strobilation started in relation to polyp densities. Days are numbered with 1 January as Day 1. Data are from 15 sites $(2003-4=$ Year $1,2004-5=$ Year 2$)$ or 14 sites $(2005-6=$ Year 3$)$

Fig. 5. (A) Mean daily temperature, (B) salinity, and (C) daily total light readings underneath marina floats in Cornet Bay, Washington, USA, for 1 December to 28 February in 2003-4 (Year 1), 2004-5 (Year 2), and 2005-6 (Year 3). Approximate start dates of strobilation of Aurelia labiata polyps are shown by arrows. 1 January is Day 1

(Pearson product moment correlation, $R=-0.292, \mathrm{p}=$ 0.084). $H_{03}$ could not be rejected.

- $H_{04}$ : pre-strobilation temperatures did not differ among years. Cornet Bay water temperatures were especially warm $\left(8.5\right.$ to $\left.9.1^{\circ} \mathrm{C}\right)$ for nearly 1 mo $(9$ December 2004 to 4 January 2005) when polyps strobilated earliest among the 3 years (Fig. 5A). Temperature data

did not pass tests for normality with any transformation and were therefore analyzed by a non-parametric test. The pre-strobilation mean daily water temperatures were significantly warmer in Year $2\left(8.5^{\circ} \mathrm{C}\right)$ than in Year $1\left(7.8^{\circ} \mathrm{C}\right)$, but not in Year $3\left(8.4^{\circ} \mathrm{C} ;\right.$ Kruskal-Wallis 1-way ANOVA on ranks; pair-wise comparisons by Dunn's method, Table 3). The pre-strobilation temperatures 
Table 3. Means and ranges of polyp densities, daily temperature, salinity, and daily total light underneath marina floats in Cornet Bay, and total daily precipitation at the Seattle-Tacoma Airport, Washington, USA, for pre-strobilation dates 1 December to 6 January in 3 periods $(2003-4=$ Year $1,2004-5=$ Year 2, 2005-6 $=$ Year 3). Data are presented as means \pm SE and ranges. Different letters $(a, b)$ indicate significantly different multiple comparison groups. $\mathrm{p}<0.05$ was considered significant. ND: no data

\begin{tabular}{|lccccc|}
\hline Year & Polyp density $\left(\right.$ no. $\left.\mathrm{cm}^{-2}\right)$ & Temperature $\left({ }^{\circ} \mathrm{C}\right)$ & Salinity & Precipitation $(\mathrm{mm})$ & Light $($ lux d \\
Year 1 & $10.0 \pm 0.5$ & $7.78 \pm 0.15 \mathrm{a}$ & $26.35 \pm 0.24$ & $3.6 \pm 0.6 \mathrm{ab}$ & $\mathrm{ND}$ \\
& $6.6-12.8$ & $5.61-8.74$ & $23.55-28.27$ & $0-16.5$ & 2.5 \\
Year 2 & $10.0 \pm 0.4$ & $8.47 \pm 0.06 \mathrm{~b}$ & $26.06 \pm 0.28$ & $2.8 \pm 0.8 \mathrm{a}$ & $2161 \pm 146$ \\
& $7.6-11.7$ & $7.70-9.13$ & $21.60-28.82$ & $0-20.8$ & $1217-3516$ \\
Year 3 & $8.9 \pm 0.2$ & $8.40 \pm 0.04 \mathrm{~b}$ & $\mathrm{ND}$ & $7.6 \pm 1.4 \mathrm{~b}$ & $1630 \pm 84$ \\
& $7.3-10.1$ & $7.84-8.95$ & & $0-33.8$ & $476-2541$ \\
Test & ANOVA & Kruskal-Wallis & $t$-test & Kruskal-Wallis & Mann-Whitney \\
Test statistic & $F_{2,43}=3.944$ & $H_{2}=19.053$ & $t_{66}=0.777$ & $H_{2}=9.238$ & $T_{30}=1051.00$ \\
p & 0.031 & $<0.001$ & 0.440 & 0.010 & 0.014 \\
\hline
\end{tabular}

were warmest in Year 2 when polyps strobilated earlier than in other years. $H_{04}$ was rejected.

- $H_{05}$ : pre-strobilation salinities or precipitation did not differ among years. Mean daily salinity data were available only for Year 1 and Year 2 (Fig. 5B). Pre-strobilation salinities did not differ significantly between those 2 years ( $t$-test, Table 3 ); however, pre-strobilation precipitation differed significantly among years (Kruskal-Wallis 1-way ANOVA on ranks), being much greater in Year 3 than in Year 1 and Year 2 (Dunn's method; Table 3, Fig. 6), which could have lowered salinities in Year 3 to less than those in Year 1 and Year 2. $H_{05}$ was rejected.

- $H_{06}$ : light intensities preceding strobilation did not differ among years. Total daily light measurements were available only for Year 2 and Year 3 (Fig. 5C). Light intensities in Year 2 were elevated in early and late December and early January. Lux data did not pass the equal variance test. The pre-strobilation light intensities were greater in Year 2 than in Year 3, and the difference was significant (Mann-Whitney rank sum test; Table 3). Strobilation began after a period of elevated light intensities in late December to early January in Year 2, and after light intensities began to rise in mid-February in Year 3. $H_{06}$ was rejected.

\section{DISCUSSION}

\section{Polyp density effects on strobilation}

Extensive colonies of Aurelia labiata polyps cover the underwater surfaces of polystyrene and polyethylene floatation blocks in Cornet Bay Marina (Hoover \& Purcell 2009). These uniform surfaces had cover of polyps averaging $\sim 60 \%$ (densities of $\sim 9$ polyps $\mathrm{cm}^{-2}$ ) with few competitors for space ( 2 to $6 \%$ cover) beneath the floating covered docks. Higher A. aurita polyp den- sities occurred on 3-dimensional attached invertebrates (Table 4). No large predators of polyps, such as nudibranchs, were seen on any sampling date under the marina floats.

Peak mean percentages of strobilating polyps for Aurelia labiata differed from about 40 to $86 \%$ among years in Cornet Bay. These were similar to those observed for $A$. aurita, which ranged from $10 \%$ in Kagoshima Bay (Miyake et al. 2002) to $40 \%$ in Urazoko Bay, Japan (Yasuda 1988), and $80 \%$ in the Kiel Bight, Germany (Thiel 1962). Nearly all polyps strobilated in some Cornet Bay sites, as seen for A. aurita (Watanabe $\&$ Ishii 2001, Miyake et al. 2002). The mean number of disks for A. labiata $(\sim 10)$ was similar to that reported for A. aurita (Miyake et al. 2002).

Polyp densities did not have significant effects on the amount or time of strobilation in Cornet Bay, where densities at strobilation ranged from 6.3 to 12.8 polyps $\mathrm{cm}^{-2}$ (Fig. 4). This result contrasts with that for Aurelia sp. in Tasmania, Australia, where almost no polyps strobilated at 1 location with low density ( $\sim 7$ polyps $\mathrm{cm}^{-2}$ ), but 30 to $82 \%$ strobilated at another location with high density $\left(\sim 30\right.$ polyps $\left.\mathrm{cm}^{-2}\right)$; the authors concluded that density-dependent effects were important to strobilation (Willcox et al. 2008). In our study, polyp density was rejected as a source of interannual differences in strobilation.

\section{Temperature effects on strobilation}

Temperature had the strongest effects on strobilation (reviewed by Purcell 2005, 2007, Liu et al. 20098). In the laboratory, warm temperatures increased the percentages of polyps producing jellyfish, and the numbers of jellyfish produced (Purcell et al. 1999, Purcell 2007). For Aurelia labiata at ambient salinity (27), 4 times more polyps strobilated at $10^{\circ} \mathrm{C}$ than at $7^{\circ} \mathrm{C}$, 

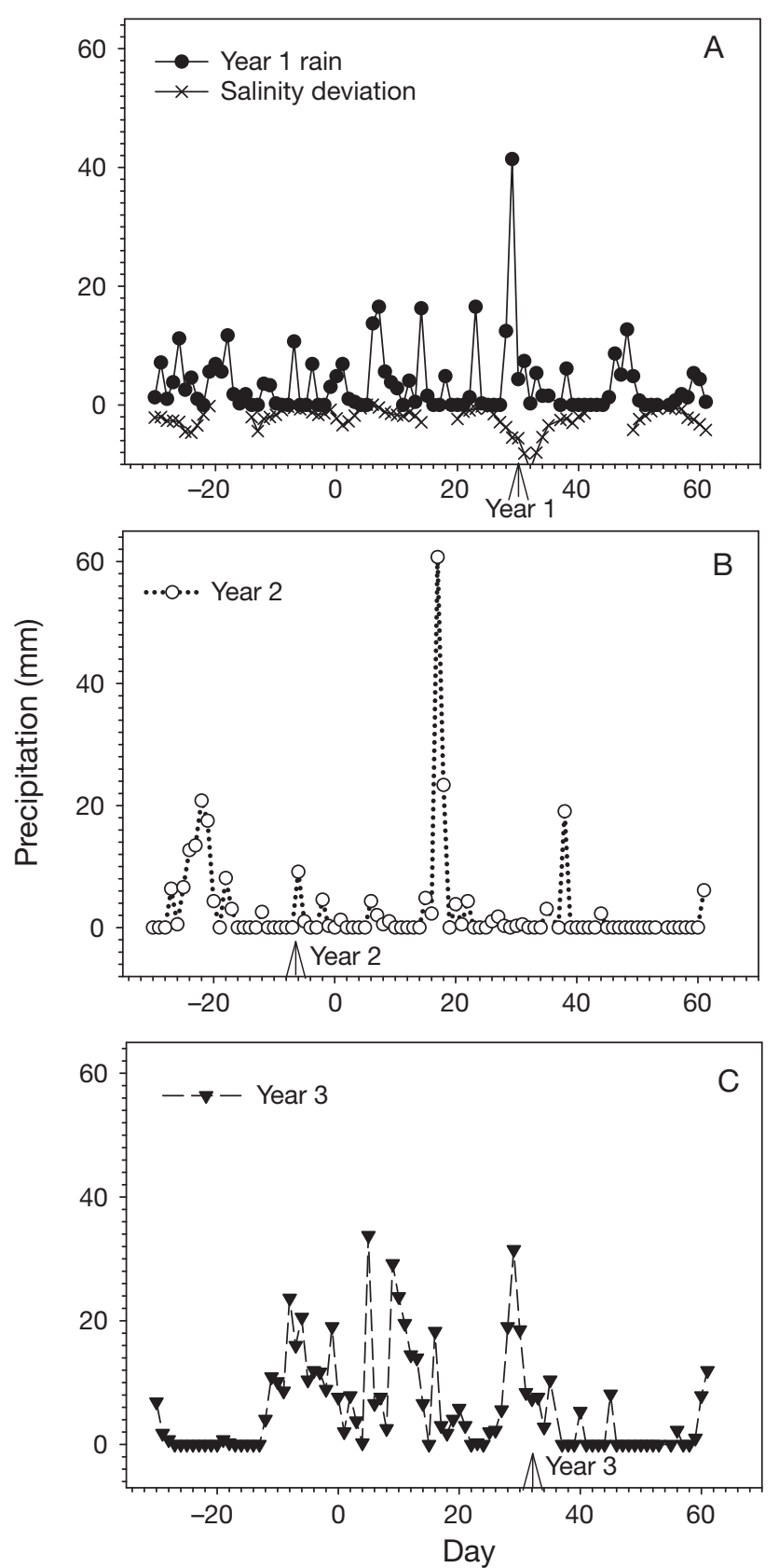

Fig. 6. Aurelia labiata. Daily precipitation recorded at the Seattle-Tacoma airport, Washington, USA, before and during 3 periods of strobilation: (A) Year 1 (2003-4), (B) Year 2 (2004-5), and (C) Year 3 (2005-6). For Year 1, deviation of salinity from the average (offset by -2 salinity units) in Cornet Bay shows the close correspondence of rain and salinity changes. Approximate start dates of strobilation of polyps are shown by arrows. 1 January is Day 1

and the number of ephyrae produced per polyp increased dramatically $\left(11.3 \%\right.$ per $1^{\circ} \mathrm{C}$ warming; Purcell 2007). Likewise, in Cornet Bay, more polyps strobilated in 2004-5 (Year 2) when pre-strobilation water temperatures were warm. In Year 2, 2.9 times more polyps strobilated than in Year 1 when mean prestrobilation temperatures differed by only $0.69^{\circ} \mathrm{C}$, and 1.6 times more polyps strobilated than in Year 3 when pre-strobilation temperatures differed by only $0.07^{\circ} \mathrm{C}$.

Production of Aurelia spp. jellyfish occurred earlier at elevated temperatures. At ambient salinity (27) in the laboratory, polyps at $10^{\circ} \mathrm{C}$ began strobilating an average of $29 \mathrm{~d}$ before polyps at $7^{\circ} \mathrm{C}$; strobilation also was completed more quickly at $10^{\circ} \mathrm{C}(28 \mathrm{~d})$ than at $7^{\circ} \mathrm{C}$ (33 d; Purcell 2007). Ephyrae appeared $~ 60$ d earlier in Southampton Water, UK, when minimum winter temperature was warm $\left(6.5^{\circ} \mathrm{C}\right)$ than when it was $\operatorname{cool}\left(4^{\circ} \mathrm{C}\right.$; Lucas 2001). Similarly, Aurelia sp. polyps strobilated earlier in Tasmania in 2004 when pre-strobilation temperatures were warmer than in 2003 (Willcox et al. 2008). Likewise, in Cornet Bay, the earliest strobilation occurred during Year 2 when temperatures were warmest among the 3 yr examined (Fig. 5, Table 3). The cold period in Year 1 may have retarded strobilation relative to Year 2. Our field data also agree with laboratory data (Purcell 2007) indicating that polyps completed strobilation in approximately 1 mo at $7^{\circ} \mathrm{C}$.

Aurelia aurita ephyrae appear after cooling in most waters studied (reviewed by Lucas 2001); however, polyps chilled in the laboratory did not strobilate until warmed (Purcell 2007, Liu et al. 2009). Strobilation of A. aurita occurred at the annual temperature minimum of $\sim 8^{\circ} \mathrm{C}$ in Kagoshima Bay (Miyake et al. 2002). Strobilation by Aurelia sp. began at the end of the annual low temperature period at $\sim 10.5^{\circ} \mathrm{C}$ in Tasmania (Willcox et al. 2008). In Cornet Bay, strobilation in A. labiata occurred after the major seasonal cooling when temperatures had risen slightly $\left(\sim 7\right.$ to $8^{\circ} \mathrm{C}$, Fig. 1). Strobilation occurred about 3 to 4 wk after abrupt cooling began in all years (Fig. 5A). We suggest that warming after cooling in combination with increased light following low light may stimulate strobilation. This is consistent with strobilation in Chrysaora quinquecirrha in Chesapeake Bay, USA (Purcell et al. 1999).

\section{Salinity effects on strobilation}

Low salinity reduced and retarded strobilation of Aurelia labiata polyps. In the laboratory, the number of polyps strobilating was reduced by $\sim 60 \%$, and strobilation averaged $20 \mathrm{~d}$ later at salinity 20 than at 27 (Purcell 2007). In Cornet Bay, pre-strobilation daily mean salinities did not differ significantly between Year 1 and Year 2. Salinity in situ varied mostly over a range of 4 , but abrupt decreases of as much as 11 due to rainstorms occurred and persisted for several days (Figs. 5 \& 6). Our field data and the laboratory results suggest that low salinity could have reduced and retarded stro- 
Table 4. Densities of Aurelia spp. polyps reported from natural and artificial substrates

\begin{tabular}{|lccl|}
\hline Species & Substrate & Polyp densities (no. $\mathrm{cm}^{-2}$ ) & \multicolumn{1}{c|}{ Source } \\
\hline A. aurita & Settling plates & $6-40$ & Gröndahl (1988) \\
A. aurita & Mussel shells & $7.3-17.6$, max. 88 & Miyake et al. (2002) \\
A. aurita & Polystyrene & $3.1-18.5$ & Miyake et al. (2002) \\
Aurelia sp. & Mussel shells & means 7.3 and 31.3 & Willcox et al. (2008) \\
A. labiata & Polystyrene & $6.3-12.8$ & Present study \\
\hline
\end{tabular}

bilation in Year 1 relative to Year 2. Although no salinity data are available for Year 3 for Cornet Bay, rainfall can be used as a proxy for salinity to compare the $3 \mathrm{yr}$; total pre-strobilation precipitation data show Year 3 to have much greater rainfall $(1298 \mathrm{~mm})$ than either Year $1(233 \mathrm{~mm})$ or Year 2 (147 mm). The timing of strobilation followed the pattern of rainfall, with strobilation being latest in Year 3 followed by Year 1 and Year 2; however, an intermediate number of polyps strobilated in Year 3 relative to the other years.

Salinity is an important factor for strobilation in other species. Salinity below 10 severely reduced strobilation in Chrysaora quinquecirrha polyps from Chesapeake Bay, where strobilation occurs in early spring when salinity is decreasing, but temperature and light are increasing (Purcell et al. 1999). Young Phyllorhiza punctata appeared in spring when salinity and temperature increased after the annual lows in Western Australia (Rippingale \& Kelly 1995). Reduced salinity and rainstorms stimulated strobilation of Catostylus mosaicus polyps (Pitt \& Kingsford 2003). Recruitment of cubozoans was also associated with rainstorms (Gordon et al. 2004). Timing of strobilation relative to salinity could be especially important for estuarine species to avoid being swept offshore by seasonal floods.

\section{Combined effects of temperature and salinity on colony growth and strobilation}

Environmental changes will affect the sizes of the benthic polyp colonies as well as their production of jellyfish. Temperature, but not salinity, significantly affected budding of Aurelia sp. polyps over $31 \mathrm{~d}$ (Willcox et al. 2007). Temperature, salinity, and their interaction significantly affected the numbers of buds produced by A. labiata polyps, with the least budding in the coolest, least saline treatment $\left(142 \mathrm{~d}\right.$ at $7^{\circ} \mathrm{C}$, salinity 20; Purcell 2007).

Interannual differences in strobilation in situ exceeded predictions from laboratory results. We predicted the percentages of polyps strobilating (\%Strob) from conditions in Cornet Bay by entering the mean prestrobilation temperatures $(T)$ and salinities $(S)$ mea- sured in Year 1 and Year 2 in Purcell's (2007) equation: \%Strob $=-67.17+$ $8.59 \times T+0.17 \times S$. The predicted $\%$ Strob in Year 2 was only $6 \%$ greater than in Year 1; however, in Cornet Bay, the mean percentage of polyps that strobilated in Year 2 was 35\% greater than in Year 1. Similarly, we estimated differences in the number of days to strobilation $(D)$ from the mean prestrobilation temperatures and salinities in Year 1 and Year 2 in Cornet Bay from Purcell's (2007) equation: $D=111.51-3.55 \times T-0.63 \times S$. The predicted beginning of strobilation was only $2 \mathrm{~d}$ earlier in Year 2 than in Year 1; however, in Cornet Bay, strobilation began $23 \mathrm{~d}$ earlier in Year 2 than in Year 1. These calculations suggest that factors in addition to temperature and salinity must contribute to the intensity and timing of strobilation.

\section{Effects of light on strobilation}

Laboratory results on the effects of light on strobilation depend on the experimental protocols. Greater exposure to light in conditions similar to those under the Cornet Bay marina floats accelerated strobilation by Aurelia labiata polyps, with polyps exposed to the most light (12 $\mathrm{h} \mathrm{d}^{-1}$ at 52 lux or $7488 \operatorname{lux~d}^{-1}$ ) strobilating more quickly than in other treatments (1248 to 4992 lux d $^{-1}$; Purcell 2007). Liu et al. (2009) found that A. aurita polyps in 8064 and 53568 lux d $^{-1}$ (our conversion) produced more ephyrae than those in the dark at 20 and $30^{\circ} \mathrm{C}$, but not at $25^{\circ} \mathrm{C}$. By contrast, other studies on $A$. aurita reported reduced strobilation in light versus dark (Custance 1964, Ishii \& Shioi 2003). Light exposure was not reported by Custance (1964). Light treatments in Ishii \& Shioi (2003) were higher (14400 and 43200 lux $\mathrm{d}^{-1}$, our conversion) than in Purcell (2007) but similar to Liu et al. (2009). High light exposure may inhibit strobilation while low light stimulates strobilation.

In Cornet Bay, the earliest strobilation was observed in Year 2, when light was high relative to Year 3 during December and early January (pre-strobilation) and during strobilation (Fig. 5C). We suggest that increased light following low light stimulates strobilation. If the stimulus were photoperiod, strobilation would start on the same day each year. By use of the difference in time to strobilation (19.7 d) between low (1248 lux d $\mathrm{d}^{-1}$ ) and high (7488 lux d $\mathrm{d}^{-1}$ ) light treatments (Purcell 2007), and the mean lux $\mathrm{d}^{-1}$ in Cornet Bay (Table 3), we calculated that polyps in Cornet Bay would have strobilated $4.2 \mathrm{~d}$ earlier in Year 2 than in Year 3, which is much less than the difference in situ (28 d). The high 
light occurring throughout the strobilation period in Year 2 could have augmented strobilation.

Differences in the time of strobilation in situ were more dramatic relative to measured environmental factors than in the laboratory. We suggest that the combined effects of temperature, salinity, and light were important in determining the amount and time of strobilation in situ.

\section{Effects of food on strobilation}

Although zooplankton densities were not monitored in Cornet Bay, they were at the annual minimum in December and increased thereafter during 2003 to 2006 in East Sound, $35 \mathrm{~km}$ distant from Cornet Bay (J. Purcell et al. unpubl.). Polyps in treatments in which food was unavailable for $2 \mathrm{wk}$ began to strobilate immediately when food was restored (Purcell 2007), and starvation has been suggested to stimulate strobilation (Arai 1997, Ishii \& Watanabe 2003). Abundant food increased production of jellyfish in Chrysaora quinquecirrha and Moerisia lyonsi (Purcell et al. 1999, Ma \& Purcell 2005). Therefore, increased food after its depletion may also stimulate strobilation.

\section{Interactive effects of temperature, salinity, and light on the food web and strobilation}

Strobilation in Aurelia labiata occurred in situ when temperature, light, and zooplankton levels were just past the annual minima and beginning to increase. Strobilation in Chrysaora quinquecirrha also occurs in increasing temperatures (Purcell et al. 1999), and more jellyfish occurred in warm years with more light and high salinity (Purcell \& Decker 2005). Strobilation in A. aurita was accelerated by light in cool temperature $\left(20^{\circ} \mathrm{C}\right)$, and by high temperatures $\left(25,30^{\circ} \mathrm{C}\right)$ in tropical Taiwan (Liu et al. 2009). We suggest that strobilation in Aurelia spp., and perhaps many species, may be stimulated in situ by increasing temperature, rain, and light. Those conditions stimulate plankton production, which would provide increased food for the newly produced jellyfish.

High plankton production occurs in the spring when rains have delivered nutrients and both temperature and light increase. Coordination of reproduction with the seasonal cycles of temperature, salinity, light, and production is common in terrestrial and aquatic ecosystems. It is obviously important for polyps to produce ephyrae when their small planktonic prey are abundant. More polyps strobilated and strobilation was earliest in Year 2 when temperature and light were high in Cornet Bay. Zooplankton densities, measured in nearby East Sound, were also highest in Year 2 (J. Purcell et al. unpubl.). We suggest that high light, temperature, and zooplankton coincided in Year 2 and increased and accelerated strobilation relative to Year 1 and Year 3. Future studies that monitor polyps, temperature, salinity, light, and zooplankton in situ and experiments that focus on the interactive effects of these factors are needed.

With warmer water temperatures predicted due to global warming (IPCC 2007), blooms of Aurelia spp. and other temperate species may be larger and occur earlier. Future changes in insolation and salinity are more difficult to predict given that anticipated changes in cloud cover and precipitation will depend on the effects of many factors (IPCC 2007).

Acknowledgements. This research was funded in part by NSF ADVANCE Fellows Award no. OCE-0137419. RAH was supported by The Charles and June Ross Foundation and the Biology Department of Western Washington University. We greatly appreciate Shannon Point Marine Laboratory for providing space, support, and equipment, notably the underwater camera, hydrolab, and imaging program. We thank Dr. B. Bingham for telling us about the polyp colonies, and Mr. Dundee, owner of the Cornet Bay Marina, for allowing us to conduct experiments at his facility.

\section{LITERATURE CITED}

Arai MN (1997) A functional biology of Scyphozoa. Chapman \& Hall, London

Custance DRN (1964) Light as an inhibitor of strobilation in Aurelia aurita. Nature 204:1219-1220

Gordon M, Hatcher C, Seymour J (2004) Growth and age determination of the tropical Australian cubozoan Chiropsalmus sp. Hydrobiologia 530-531:339-345

Goy J, Morand P, Etienne M (1989) Long-term fluctuations of Pelagia noctiluca (Cnidaria, Scyphomedusa) in the western Mediterranean Sea. Prediction by climatic variables. Deep-Sea Res 36:269-279

Gröndahl F (1988) A comparative ecological study of the scyphozoans Aurelia aurita, Cyanea capillata and C. lamarckii in the Gullmar Fjord, western Sweden, 1982 to 1986. Mar Biol 97:541-550

Hernroth L, Gröndahl F (1985) On the biology of Aurelia aurita (L.). 2. Major factors regulating the occurrence of ephyrae and young medusae in the Gullmar Fjord, western Sweden. Bull Mar Sci 37:567-576

Hoover RA, Purcell JE (2009) Substrate preferences of scyphozoan Aurelia labiata polyps among common dockbuilding materials. Hydrobiologia 616:259-267

IPCC (2007) Summary for policymakers. In: Solomon S, Qin D, Manning M, Chen Z and others (eds) Climate change 2007: the physical science basis. Contribution of Working Group I to the 4th assessment report of the Intergovernmental Panel on Climate Change. Cambridge University Press, Cambridge

Ishii H, Shioi H (2003) The effects of environmental light condition on strobilation in Aurelia aurita polyps. Sessile Org 20:51-54

Ishii H, Watanabe T (2003) Experimental study of growth and asexual reproduction in Aurelia aurita polyps. Sessile Org 20:69-73 
Keen S (1991) Clonal dynamics and life history evolution in the jellyfish Aurelia aurita. PhD thesis, University of California, Berkeley, CA

Liu WC, Lo WT, Purcell JE, Chang HH (2009) Effects of temperature and light intensity on asexual reproduction of the scyphozoan, Aurelia aurita (L.) in Taiwan. Hydrobiologia 616:247-258

Loeb MJ (1973) The effect of light on strobilation in the Chesapeake Bay sea nettle Chrysaora quinquecirrha. Mar Biol 20:144-147

Lu N, Liu C, Guo P (1989) Effect of salinity on larva of edible medusae (Rhopilema esculenta Kishinouye) at different development phases and a review on the cause of jellyfish resources falling greatly in Liaodong Bay. Acta Ecol Sin 9: 304-309

Lucas CH (2001) Reproduction and life history strategies of the common jellyfish, Aurelia aurita, in relation to its ambient environment. Hydrobiologia 451:229-246

Ma X, Purcell JE (2005) Temperature, salinity and prey effects on polyp versus medusa bud production of the invasive hydrozoan, Moerisia lyonsi. Mar Biol 147:225-234

Miyake H, Terazaki M, Kakinuma Y (2002) On the polyps of the common jellyfish Aurelia aurita in Kagoshima Bay. J Oceanogr 58:451-459

Molinero JC, Ibanez F, Nival P, Buecher E, Souissi S (2005) North Atlantic climate and northwestern Mediterranean plankton variability. Limnol Oceanogr 50:1213-1220

Pitt KA, Kingsford MJ (2003) Temporal and spatial variation in recruitment and growth of medusae of the jellyfish, Catostylus mosaicus (Scyphozoa: Rhizostomaeae). Mar Freshw Res 54:117-125

Purcell JE (2005) Climate effects on formation of jellyfish and ctenophore blooms: a review. J Mar Biol Assoc UK 85: 461-476

Purcell JE (2007) Environmental effects on asexual reproduction rates of the scyphozoan, Aurelia labiata. Mar Ecol Prog Ser 348:183-196

Editorial responsibility: Otto Kinne, Oldendorf/Luhe, Germany
Purcell JE, Decker MB (2005) Effects of climate on relative predation by scyphomedusae and ctenophores on copepods in Chesapeake Bay during 1987-2000. Limnol Oceanogr 50:376-387

Purcell JE, White JR, Nemazie DA, Wright DA (1999) Temperature, salinity and food effects on asexual reproduction and abundance of the scyphozoan Chrysaora quinquecirrha. Mar Ecol Prog Ser 180:187-196

Purcell JE, Uye SI, Lo WT (2007) Anthropogenic causes of jellyfish blooms and direct consequences for humans: a review. Mar Ecol Prog Ser 350:153-174

Rippingale RJ, Kelly SJ (1995) Reproduction and survival of Phyllorhiza punctata (Cnidaria: Rhizostomeae) in a seasonally fluctuating salinity regime in Western Australia. Mar Freshw Res 46:1145-1151

Silverstone M, Tosteson T, Cutress C (1977) The effect of iodine and various iodocompounds on initiation of strobilation in Aurelia. Gen Comp Endocrinol 32:108-113

Spangenberg DB (1968) Recent studies of strobilation in jellyfish. Oceanogr Mar Biol Annu Rev 6:231-247

Thiel H (1962) Untersuchungen über die Strobilisation von Aurelia aurita Lam. an einer Population der Kieler Förde. Kieler Meeresforsch 18:198-230

Watanabe T, Ishii H (2001) In situ estimation of ephyrae liberated from polyps of Aurelia aurita using settling plates in Tokyo Bay, Japan. Hydrobiologia 451:247-258

> Willcox S, Moltschaniwskyj NA, Crawford C (2007) Asexual reproduction in scyphistomae of Aurelia sp.: effects of temperature and salinity in an experimental study. J Exp Mar Biol Ecol 353:107-114

Willcox S, Moltschaniwskyj NA, Crawford CM (2008) Population dynamics of natural colonies of Aurelia sp. scyphistomae in Tasmania, Australia. Mar Biol 154: 661-670

Yasuda T (1988) Studies on the common jelly-fish, Aurelia aurita (Linne). Jpn Fish Res Conserv Assoc, Tokyo (in Japanese with English abstract)

Submitted: May 22, 2008; Accepted: October 21, 2008 Proofs received from author(s): January 9, 2008 